\title{
Book Review: The Feel of the Road
}

\author{
Gregory B. Sullivan, MD \\ Thomas Jefferson University Hospital
}

Follow this and additional works at: https://jdc.jefferson.edu/jeffjpsychiatry

Part of the Psychiatry Commons

Let us know how access to this document benefits you

\section{Recommended Citation}

Sullivan, MD, Gregory B. (1987) "Book Review: The Feel of the Road," Jefferson Journal of Psychiatry. Vol. 5 : Iss. 1 , Article 11.

DOI: https://doi.org/10.29046/JJP.005.1.012

Available at: https://jdc.jefferson.edu/jeffjpsychiatry/vol5/iss $1 / 11$

This Article is brought to you for free and open access by the Jefferson Digital Commons. The Jefferson Digital Commons is a service of Thomas Jefferson University's Center for Teaching and Learning (CTL). The Commons is a showcase for Jefferson books and journals, peer-reviewed scholarly publications, unique historical collections from the University archives, and teaching tools. The Jefferson Digital Commons allows researchers and interested readers anywhere in the world to learn about and keep up to date with Jefferson scholarship. This article has been accepted for inclusion in Jefferson Journal of Psychiatry by an authorized administrator of the Jefferson Digital Commons. For more information, please contact: JeffersonDigitalCommons@jefferson.edu. 


\title{
The Feel of the Road
}

\author{
A PRIMER FOR PSYCHOTHERAPISTS \\ Kenneth Mark Colby, M.D. \\ New York, John Wiley and Sons, \\ 1951,167 pages, $\$ 29.95$
}

Gregory B. Sullivan, M.D.

\begin{abstract}
We can make our minds so like still water that beings gather about us that they may see, it may be, their own images, and so live for a moment with a clearer, perhaps even with a fiercer life because of our quiet.
\end{abstract}

W. B. Yeats

Recently, while driving in Ireland on the "wrong" side of the road, I experienced a sense of déjà vu for my first days as a psychotherapist. Nothing before had evoked quite the same sense of disorientation in undertaking what is very nearly the familiar reality, but has all-important differences. It is this disarming near-similarity that both enlists and confounds common sense and previous experience, of conversation or counseling, of driving on the right side, that so unnerves the beginning resident-as-therapist. Though I warily grew adjusted within days to driving on the left in uncomplicated traffic, the first unmarked turnoff would have me reverting to stateside habit, lurching onto the righthand side, creating a spiral of anxiety. Likewise, as an inexperienced therapist have I found more ingrained interview behaviors resurfacing whenever my anxiety level rises, causing me to slip into review-of-systems, medication bargaining, or concrete problem-solving, hammering at screws with predictable result. How then will the resident learn to drive in this foreign land, and how amidst the catecholamine surge will he ever achieve Yeats' quiet?

For residents attempting thus to drive and read the map at the same time, Kenneth Mark Colby's 1951 text, A Primer for Psychotherapists, has much to commend it. Colby confirms the primary role of apprenticeship to an experienced practitioner; he offers his book as a "companion to the indispensible personal instruction and observation which provide the practical base for psychotherapy" (1). While brief, the book is enriched by transcribed clinical examples. After a brief outline of the basic theory, Colby introduces The Patient ("Who comes to therapy; Why he comes; Who is chosen; What he fears; What he hopes") and The Therapist ("His past; His present; His task; Countertransferences"), before setting out time and space conditions for the interview. Therapeutic goals, strategies, and techniques are then discussed as they evolve through 
the beginning, middle, and end stages of therapy. The book finishes with a less cohesive discussion of therapy in schizophrenic patients, a weak point with a rather abrupt ending.

In its favor are the author's uncondescendingly clear style throughout, as well as his welcome emphasis on the somewhat neglected area of the middle course of therapy, where residents whose coursework often concentrates on introduction and termination often founder on what to do between hello and goodbye. Most important, the cogent and persistent grounding of technique in psychodynamic theory prevents this work from serving as another mechanistic where-do-I-arrange-my-office-chairs manual.

Thirty-five years from publication, the book nonetheless retains a realistic viewpoint on the resident as beginning therapist, inhabiting the office "relegated to the end of the mop closet near the elevator shaft." The book speaks to those in the trenches with the somatizers and secondary-gainers about rational patient selection, about workable goals between grandiosity and nihilism, about frequent terminations while rotating through clinics. Residents will find it difficult, however, to heed Colby's utopian advice that "if you have a pain or feel sleepy or 'hung over', then you should not see patients until your malaise has cleared" (likewise with the "uncontrollably 'crabby', anxious, or depressed" resident), to say nothing of his suggestion to take an hour or two of the working day to "read a little, write letters, or perhaps at leisure think about countertransferences."

The content is most dated, predictably, in the area of medication: "some patients entering therapy are already taking drugs, usually benzedrine or barbiturates..." Colby's opinion at the time that drugs should not be given except in real crisis might be reconsidered in this era of, for example, effective antidepressants. Similarly, as geropsychiatry is better understood, Colby's maximum age cutoff for his "most suitable patient type" is not justifiable, as seen in Dr. Mark Miller's recent article in The Jefferson Journal of Psychiatry (2).

On some of therapy's nuts-and-bolts decisions, Colby does some diplomatic fence-sitting on personal analysis for residents, and is similarly temperate in his defense of using a couch for non-analytic patients, as with his dismissal of note-taking in situ as well. The author inspires confidence not so much by the specific stands he takes, but by the persuasively pragmatic tone he lends to some potentially dogmatic issues; as in skillful therapy, content follows process.

It is the attention to the process of becoming a therapist that makes this primer a lasting work despite the intervening years of tremendous change in psychiatry. Colby acknowledges the special defenses, motivations, and countertransferences we inherit from previous training. He would have us recognize the handicap of a dehumanized detachment achieved in medical school, disarming us of our talismanic self-deception by clearing the already bare resident's office of "skulls, charts of the autonomic nervous system, brain models, and other medical trappings ... needless props," substituting in their stead the more 
potent tools of the psychotherapist. It's not a bad toolbox to keep with you until you've got the feel of the road.

\section{REFERENCES}

1. Colby KM: A Primer for Psychotherapists, New York, John Wiley and Sons, 1951

2. Miller MD: Using psychoanalytically oriented psychotherapy in the elderly. Jefferson Journal of Psychiatry, 4(1):13-21, 1986 